Gut, 1979, 20, 653-659

\title{
Distribution of the gut hormones in the primate intestinal tract
}

\author{
M. G. BRYANT AND S. R. BLOOM \\ From the Department of Medicine, Royal Postgraduate Medical School, Hammersmith Hospital, London
}

SUMMARY Reliable and specific radioimmunoassays have been developed for the gut hormones secretin, gastrin, cholecystokinin, pancreatic glucagon, VIP, GIP, motilin, and enteroglucagon. Using these assays, the relative pattern of distribution of the gut hormones has been determined using the same bowel extracts for all measurements. VIP occurred in high concentration in all regions of the bowel, whereas secretin, GIP, motilin, and CCK were predominantly localised in the proximal small intestine. Pancreatic glucagon was almost exclusively confined to the pancreas. Like VIP, enteroglucagon also exhibited a wide pattern of distribution but was maximal in the ileum. The acid ethanol extraction method that was used was found to be unsuitable for gastrin. On gel chromatography of the extracts, motilin and VIP eluted as single molecular species in identical position to the pure porcine peptides. CCK, pancreatic glucagon, enteroglucagon and GIP were all multiform.

Over the last decade the development of radioimmunoassays for the gut hormones has allowed their quantitative measurement both in plasma and in tissue. Although this has prompted several investigations to determine the normal distribution of these hormones in different species (Unger et al., 1961; Bloom and Bryant, 1973; Reeder et al., 1973; Rehfeld et al., 1975; Bloom et al., 1975; O'Dorisio et al., 1976), no comprehensive study has been undertaken in the primate. It is clearly impossible, however, to study complete undamaged fresh whole bowel regions from man and therefore the intestinal tracts from baboons and monkeys have been studied. Such relative 'mapping' of the accurate distribution of the gut hormones is essential to provide good baseline data for the design of additional studies to help elucidate the role played by those hormones in physiology and pathophysiology.

We have developed sensitive and specific radioimmunoassays for the classical gut hormones secretin (Häcki et al., 1977), gastrin (Russell et al., 1976), cholecystokinin (CCK), and pancreatic glucagon (Alford et al., 1977) and also for the more recently discovered hormonal peptides vasoactive intestinal peptide (VIP) (Mitchell and Bloom, 1979), gastric inhibitory peptide (GIP), motilin (Bloom et $a l ., 1976 \mathrm{~b}$ ), and enteroglucagon. These assays have been used to determine the distribution of each

Received for publication 12 February 1979 peptide throughout the primate intestinal tract using the same bowel extracts for all measurements.

\section{Methods}

\section{EXTRACTION}

The complete intestinal tract was removed after brief anaesthesia from four healthy baboons and three monkeys (Macaca Iris) all of whom had been fed on a human diet for several years. After cleansing the bowel with cold running water and rapid dissection into anatomical regions, all tissues were plunged into freezing acid ethanol $(75 \%$ ethanol containing $100 \mathrm{mmol} / 1$ hydrochloric acid at $-40^{\circ} \mathrm{C}$ ) to prevent enzymatic degradation of the peptides. The tissues were subsequently stored separately in acid ethanol at $-20^{\circ} \mathrm{C}$ until the time of extraction when they were weighed while still frozen, minced, and then homogenised at $10000 \mathrm{rpm}$ for 10-15 minutes in $5 \mathrm{ml}$ acid ethanol/g of tissue wet weight. In order to minimise losses of peptide material which may have been released during initial freezing and storage, the tissues were homogenised in the acid ethanol in which they had been stored. The resulting homogenates were allowed to stand at $4^{\circ} \mathrm{C}$ with constant stirring for one hour in order to solubilise the peptides and then centrifuged at $2500 \mathrm{~g}$ for 30 minutes. The clear supernatants were decanted and saved and the tissue pellets re-extracted another three times with $4 \mathrm{ml}, 3 \mathrm{ml}$, and finally $2 \mathrm{ml}$ 
of acid ethanol/g of tissue. After final centrifugation, the tissue debris was discarded and the supernatants from each region of the gut pooled. The extracts were neutralised and the resulting precipitate removed by further centrifugation. The precipitate was dried, redissolved in $100 \mathrm{mmol} / 1$ formic acid and assayed to determine whether any loss of hormonal immunoreactivity occurred in this precipitate. Aliquots of the supernatant peptide liquors were dried down under nitrogen and reconstituted in buffer before assay. The bulk of the peptide fraction was stored at $-20^{\circ} \mathrm{C}$ for subsequent column gel chromatographic studies of hormone immunoreactivity. In all radioimmunoassays, samples of the extracts were added in duplicate 10-fold serial dilutions ranging from $100 \mu l$ to $0.001 \mu l$ of extract per assay tube.

In order to assess the ability of each peptide hormone to withstand the extraction procedure, a series of separate pilot studies was performed. Using baboon duodenum and antrum as starting material, the recovery of endogenous hormones and of added radioactive hormone label (using ${ }^{125} \mathrm{I}$-iodinated hormone-see below) was monitored at each step of the process outlined previously. The label was introduced into the system by addition to the acid ethanol used for the first homogenisation. In an attempt to determine the degree of damage caused to each peptide during extraction, an evaluation was made of the ability of ${ }^{125}$ I-labelled hormones recovered at each step to bind to their respective antibodies. These studies allow assessment of hormone recoveries once the hormones are solublised, though not of the efficiency of the extraction procedure itself.

\section{RADIOIMMUNOASSAYS}

All assays, except that for gastrin, for which synthetic human gastrin (ICI) was used were developed to the pure natural porcine hormones. Antibodies to each peptide were raised in rabbits with the horhome coupled to bovine serum albumin (BSA) using either carbodiimide or bis diazotised benzidine. The conjugates were emulsified in complete Freund's adjuvant before immunisation. After primary immunisation the animals were boosted at three monthly intervals and antisera collected for testing 10 days after each boosting. Immunisation with glucagon produced several antisera of different specificities. One, designated RCS5, which was Cterminal reacting, was specific for pancreatic glucagon, whereas another, R59, appeared to cross-react fully with glucagon-like immunoreactivity of intestinal origin (enteroglucagon). By simultaneous measurements of an extract with both antibodies and subsequent subtraction of values obtained with
Table 1 Final antibody dilutions and assay sensitivities

\begin{tabular}{lrl}
\hline Antiserum & Final Dilution & Assay Sensitivity $(\mathrm{fmol})$ \\
\hline Pancreatic glucagon & 320000 & $0.6 \mathrm{fmol}$ \\
Total glucagon & 2400 & $1.6 \mathrm{fmol}$ \\
Gastrin & 160000 & $0.4 \mathrm{fmol}$ \\
Secretin & 280000 & $0.4 \mathrm{fmol}$ \\
CCK & 32000 & $2.0 \mathrm{fmol}$ \\
Motilin & 240000 & $0.4 \mathrm{fmol}$ \\
VIP & 320000 & $0.4 \mathrm{fmol}$ \\
GIP & 240 & $2.0 \mathrm{fmol}$ \\
\hline
\end{tabular}

RCS5, which measured only pancreatic glucagon, from those obtained with R59, which measured total glucagon-like immunoreactivity, the apparent enteroglucagon content of the extract could be determined. All antisera were tested for specificity by addition of up to $2 \mathrm{nmol}$ per assay tube of all available gut hormones. In no case was any significant degree of crossreactivity observed. Table 1 summarises final antibody dilutions and assay sensitivities. VIP, secretin, motilin, GIP, and CCK were radioactively labelled using a lactoperoxidase technique (Holohan et al., 1973), whereas a modification of the chloramine $T$ method (Hunter and Greenwood, 1962) was used for glucagon and gastrin. Iodination and label purification conditions are outlined in Table 2 , which also indicates the specific activities achieved.

The presence of a sulphate group on the only tyrosine residue in position 27 of the 33 amino acid peptide CCK makes iodination of this molecule extremely difficult. For this reason the pure natural porcine 39 amino acid peptide CCK variant was iodinated. This peptide contains the full amino acid sequence of 33-CCK with an additional N-terminal sequence of six amino acids including a nonsulphated tyrosine, thus allowing easy iodination. Both 33-CCK and 39-CCK were equally recognised by the antibody that was used which was raised to 33-CCK.

\section{Results}

In all cases, extractable hormonal immunoreactivity diluted out approximately parallel to the respective pure hormone standard curves. Extracts of heart and liver, taken as control tissues, showed no inhibition of binding of labelled hormone to antibody. The protein content of these extracts (determined by $280 \mathrm{~nm}$ absorption) was greater than that of the gut tissue extracts, thus confirming previous observations that interference by non-specific protein effects with the assays was negligible at the dilutions used.

From the pilot studies it was found that less than $10 \%$ damage was caused to the peptides by the ex- 


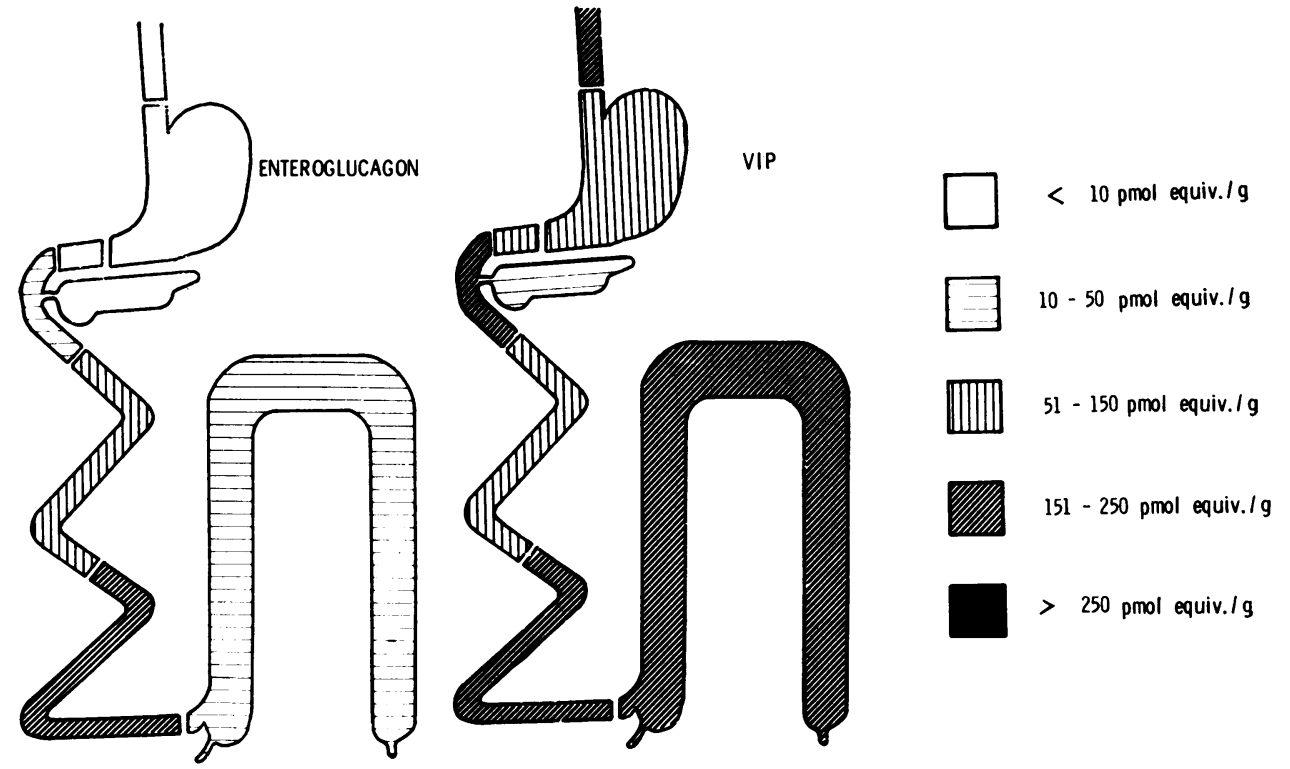

Fig. 1 Schematic representation of the baboon gut showing the relative distribution patterns of VIP and enteroglucagon.

Table 2 Hormone iodination and label purification conditions, showing resulting specific activities of purified labels $(\mu \mathrm{Ci} / \mu \mathrm{g})$

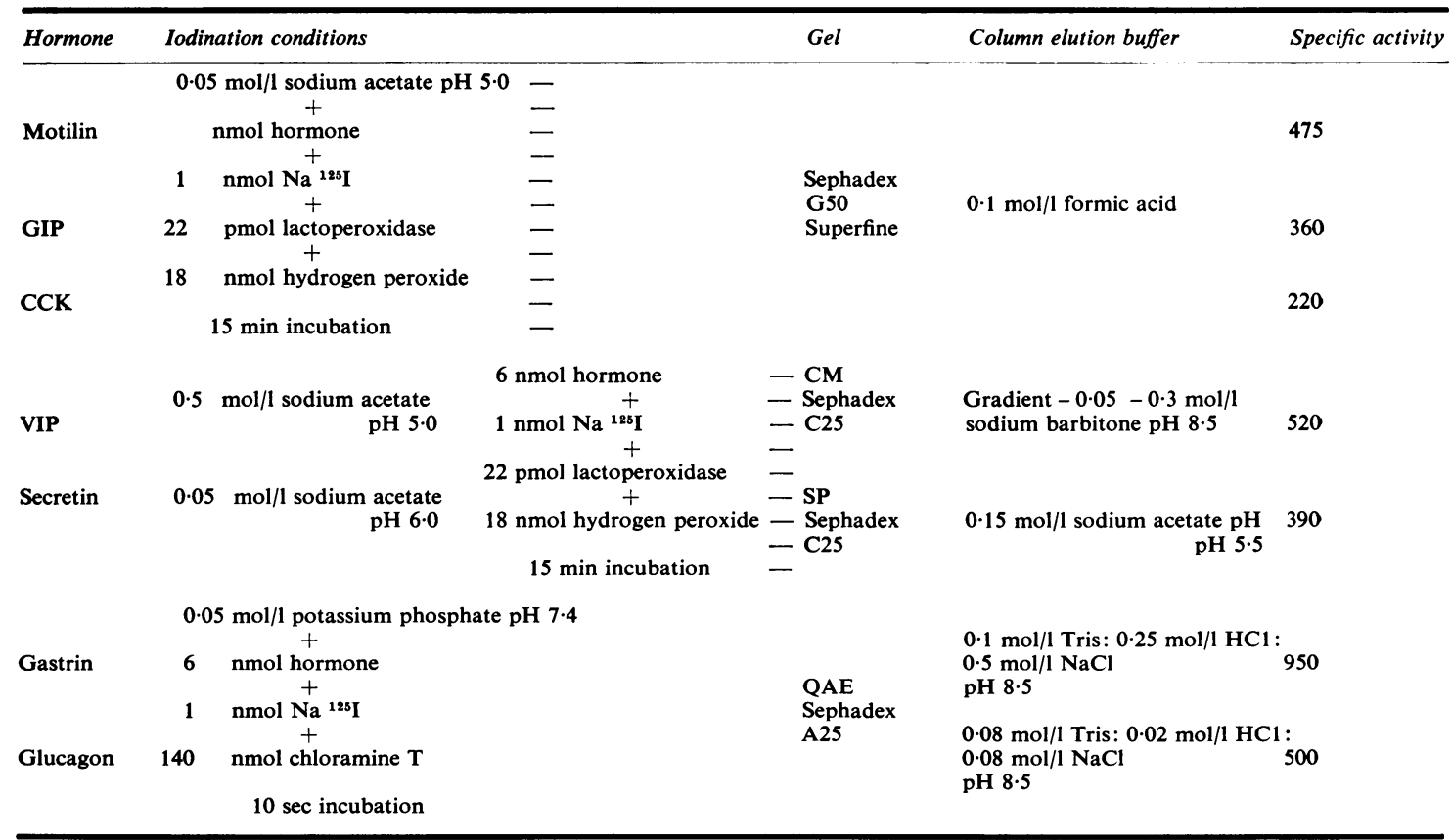



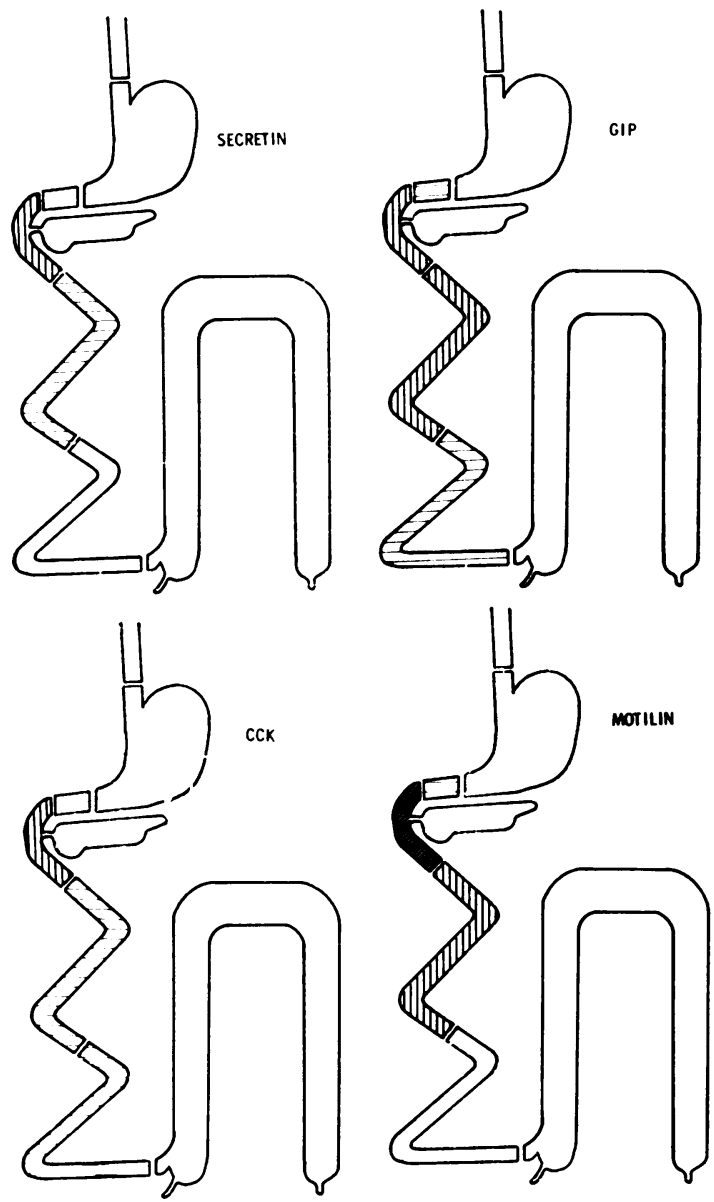

Fig. 2 Schematic representation of the baboon gut showing the relative distribution patterns of $C C K$, secretin, GIP and motilin (scale as Fig. 1).

traction procedure and, except for gastrin, recoveries of all hormones were greater than $90 \%$. After six homogenisations only $15 \%$ of ${ }_{125} \mathrm{I}$ gastrin was recovered and a similar ratio of amounts of endogenous gastrin recovered with each extraction was observed. Except for gastrin, no hormone immunoreactivity appeared in the redissolved precipitates obtained after acid alcohol neutralisation. From these data it was concluded that the acid ethanol extraction method was unsuitable for gastrin and therefore no distribution data are pesented for this hormone.

Figures 1, 2, and 3 are schematic representations of the baboon gastrointestinal tract showing the relative distribution of the gut hormones. These data are shown in greater detail in Tables 3 and 4 with hormone concentrations for both the baboon (mean \pm SEM) and monkey (mean and range). In view of the probable existence of multiple molecular forms of these peptides in tissues and the possibility of variation in the degree of their crossreactivity with the antisera employed, all results are expressed as pmol equivalents/g whole bowel wet weight with reference to the pure porcine hormones used as standards in the assays.

VIP occurred in high concentration throughout the whole gut, being maximal in the colon and duodenum. Secretin, GIP, motilin, and CCK were of highest concentration in the duodenum, the concentration decreasing distally down the gut. Both GIP and motilin immunoreactivity was observed in the stomach. Pancreatic glucagon was almost exclusively confined to the pancreas, with less than $0.01 \%$ occurring in the fundus of the stomach. The amounts of pancreatic polypeptide in the same pancreatic extracts have been reported separately (Adrian et al., 1976) but are shown here for comparison.

Like VIP, enteroglucagon immunoreactivity was also found to be widely distributed, occurring in significant quantities from fundus to colon. However, the concentration of this latter hormone increased distally along the bowel, being maximal in the terminal ileum. Table 5 shows the total bowel content for each of the gut hormones.

\section{Discussion}

Determination of the distribution pattern of the gut hormones in the primate intestinal tract has revealed several interesting features. In particular there is a remarkably close degree of correlation between the
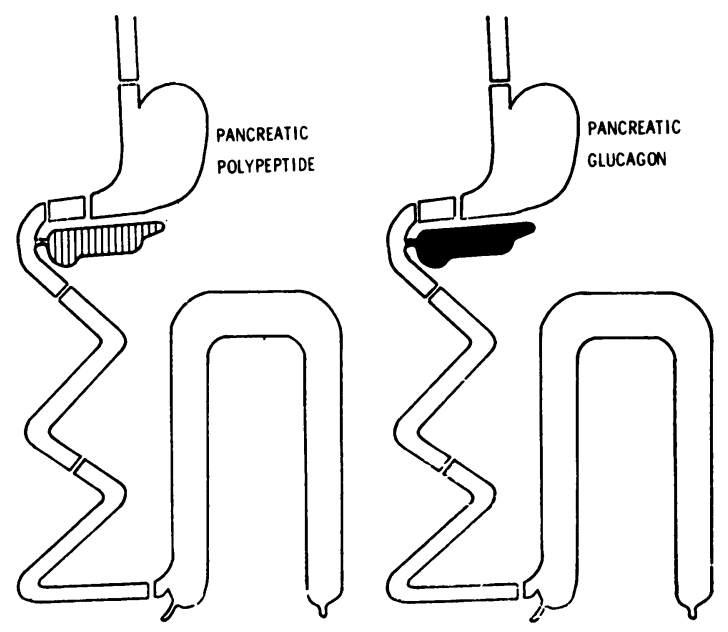

Fig. 3 Schematic representation of the baboon gut showing the relative distribution patterns of pancreatic polypeptide and pancreatic glucagon (scale as Fig. 1). 
Table 3 Gut hormone concentrations in djfferent regions of baboon gastrointestinal tract

\begin{tabular}{|c|c|c|c|c|c|c|c|c|}
\hline Region & $C C K$ & Secretin & Motilin & $G I P$ & $V I P$ & $\begin{array}{l}\text { Entero- } \\
\text { Glucagon }\end{array}$ & $\begin{array}{l}\text { Pancreatic } \\
\text { Glucagon }\end{array}$ & $\begin{array}{l}\text { Pancreatic } \\
\text { Polypeptide }\end{array}$ \\
\hline $\begin{array}{l}\text { Oesophagus } \\
\text { Fundus } \\
\text { Antrum } \\
\text { Duodenum } \\
\text { Jejunum } \\
\text { Ileum } \\
\text { Colon } \\
\text { Pancreas } \\
\text { Heart } \\
\text { Liver }\end{array}$ & $\begin{array}{l}\text { ND } \\
\text { ND } \\
\text { ND } \\
51 \pm 10 \\
33 \pm 4 \\
24 \pm 6 \\
\text { ND } \\
\text { ND } \\
\text { ND } \\
\text { ND }\end{array}$ & $\begin{array}{l}\text { ND } \\
\text { ND } \\
\text { ND } \\
62 \pm 6 \\
25 \pm 4 \\
3 \pm 0 \cdot 3 \\
\text { ND } \\
\text { ND } \\
\text { ND } \\
\text { ND }\end{array}$ & $\begin{array}{l}\text { ND } \\
4 \pm 1 \\
31 \pm 3 \\
156 \pm 8 \\
80 \pm 8 \\
6 \pm 1 \\
\text { ND } \\
\text { ND } \\
\text { ND } \\
\text { ND }\end{array}$ & $\begin{array}{l}\text { ND } \\
\text { ND } \\
45 \pm 5 \\
70 \pm 5 \\
65 \pm 9 \\
25 \pm 3 \\
\text { ND } \\
\text { ND } \\
\text { ND } \\
\text { ND }\end{array}$ & $\begin{array}{r}162 \pm 26 \\
78 \pm 5 \\
85 \pm 8 \\
185 \pm 18 \\
98 \pm 22 \\
165 \pm 38 \\
220 \pm 69 \\
30 \pm 8 \\
\text { ND } \\
\text { ND }\end{array}$ & $\begin{array}{l}\text { ND } \\
\text { ND } \\
\text { ND } \\
10 \pm 3 \\
52 \pm 9 \\
166 \pm 29 \\
14 \pm 5 \\
\text { ND } \\
\text { ND } \\
\text { ND }\end{array}$ & $\begin{array}{l}\text { ND } \\
\text { ND } \\
\text { ND } \\
\text { ND } \\
\text { ND } \\
\text { ND } \\
\text { ND } \\
5000 \pm 600 \\
\text { ND } \\
\text { ND }\end{array}$ & $\begin{array}{l}\text { ND } \\
1.9 \pm 0.3 \\
1 \cdot 4 \pm 0 \cdot 3 \\
2 \cdot 1 \pm 0 \cdot 3 \\
0.8 \pm 0 \cdot 5 \\
0.6 \pm 0.4 \\
0.8 \pm 0.3 \\
123 \pm 16 \\
\text { ND } \\
\text { ND }\end{array}$ \\
\hline
\end{tabular}

Results expressed as pmol equivalents/g whole bowel wet weight (mean $\pm \mathbf{S E M}$ ). Assay detection limits are as follows: CCK $<0.3$ pmol equivalents/g whole bowel wet weight; secretin $<0.06$; motilin $<0.06$; GIP $<0.3$; VIP $<0.06$; enteroglucagon $<0.2$; pancreatic glucagon $<0.08$; pancreatic polypeptide $<0 \cdot 1$; ND: not detectable.

Table 4 Gut hormone concentrations in different regions of monkey gastrointestinal tract

\begin{tabular}{|c|c|c|c|c|c|c|c|}
\hline Region & CCK & Secretin & Motilin & $G I P$ & $V I P$ & Enteroglucagon & $\begin{array}{l}\text { Pancreatic } \\
\text { glucagon }\end{array}$ \\
\hline $\begin{array}{l}\text { Oesophagus } \\
\text { Fundus } \\
\text { Antrum } \\
\text { Duodenum } \\
\text { Jejunum } \\
\text { Ileum } \\
\text { Colon } \\
\text { Pancreas } \\
\text { Heart } \\
\text { Liver }\end{array}$ & $\begin{array}{l}\text { ND } \\
\text { ND } \\
\text { ND } \\
61(42-71) \\
39(21-50) \\
30(28-33) \\
\text { ND } \\
\text { ND } \\
\text { ND } \\
\text { ND }\end{array}$ & $\begin{array}{l}\text { ND } \\
\text { ND } \\
\text { ND } \\
86(80-93) \\
31(26-41) \\
2(1-3) \\
\text { ND } \\
\text { ND } \\
\text { ND } \\
\text { ND }\end{array}$ & $\begin{array}{l}\text { ND } \\
4(0 \cdot 5-6) \\
30(21-40) \\
131(110-153) \\
68(51-80) \\
8(6-10) \\
\text { ND } \\
\text { ND } \\
\text { ND } \\
\text { ND }\end{array}$ & $\begin{array}{l}\text { ND } \\
\text { ND } \\
53(32-81) \\
84(79-90) \\
64(58-72) \\
20(10-36) \\
\text { ND } \\
\text { ND } \\
\text { ND } \\
\text { ND }\end{array}$ & $\begin{array}{l}86(63-110) \\
25(20-28) \\
27(16-35) \\
44(26-55) \\
55(39-65) \\
100(91-110) \\
63(53-70) \\
20(16-28) \\
\text { ND } \\
\text { ND }\end{array}$ & $\begin{array}{l}\text { ND } \\
\text { ND } \\
\text { ND } \\
5(3-8) \\
41(35-48) \\
120(106-132) \\
21(13-30) \\
\text { ND } \\
\text { ND } \\
\text { ND }\end{array}$ & $\begin{array}{l}\text { ND } \\
\text { ND } \\
\text { ND } \\
\text { ND } \\
\text { ND } \\
\text { ND } \\
\text { ND } \\
3000(2200-4169 \\
\text { ND } \\
\text { ND }\end{array}$ \\
\hline
\end{tabular}

Results expressed as pmol equivalents/g whole bowel wet weight (mean and range). Assay detection limits as in Table 3 .

baboon and monkey with regard to both relative distribution and absolute region-to-region concentrations of the gut hormones.

Although the acid alcohol method of extraction is efficient for most of the gut hormones, it is poor for gastrin. This is probably a consequence of the acidic nature of this peptide which renders it relatively insoluble in the acid conditions of the extraction.

It has been suggested that cholecystokinin is related to the gastrin family of peptides, both hormones sharing the same amino acid sequence in the Cterminal pentapeptide. The distribution and total amount of CCK in the gut, however, is different from that of gastrin reported by other workers (Nilson et al., 1973) being maximal in the duodenum and decreasing distally. This distribution pattern is

Table 5 Total amounts of gut hormones present in baboon gastrointestinal tract (nmol equivalents; mean $\pm S E M)$

\begin{tabular}{lc}
\hline Hormone & Total amount in whole bowel \\
\hline VIP & $128 \pm 32$ \\
Pancreatic glucagon & $74 \pm 9$ \\
Enteroglucagon & $44 \pm 8$ \\
Motilin & $20 \pm 2$ \\
GIP & $14 \pm 1$ \\
CCK & $7 \pm 0 \cdot 5$ \\
Secretin & $4 \pm 0 \cdot 4$ \\
\hline
\end{tabular}

in very good agreement with early bioassay data (Go et al., 1969), confirmed more recently by radioimmunoassay (Reeder et al., 1973). The lack of detection of 'cholecystokinin-like' immunoreactivity in the antrum provides additional evidence of the specificity of our CCK assay, as, despite use of an unsuitable extraction method, large quantities of gastrin were extractable from the antrum.

The distribution obtained here for secretin, with highest amounts present in the duodenum and decreasing distally down the bowel, is also in complete agreement with early bioassay data (Friedman and Thomas 1950). No secretin immunoreactivity was detectable in the stomach or colon.

Like cholecystokinin and secretin, GIP and motilin were also predominant in the proximal small bowel and undetectable in the colon. However, in contrast with the former hormones, both GIP and motilin occurred in small quantities in the stomach, particularly in the antral region.

VIP, which along with secretin, pancreatic glucagon, and GIP, is a member of the secretin 'family' of peptides, exhibits a much wider pattern of distribution than the other members of this family. Whereas secretin, GIP, and pancreatic glucagon are localised mainly in the upper small intestine and pancreas, VIP occurs in high concentrations throughout the length of the gut from oesophagus to rectum, 
including the pancreas. The physiological role of VIP is unknown but it possesses an unusually wide spectrum of biological actions (Said and Mutt, 1970) and has a very short half-life in plasma (Domschke et al., 1978; Modlin et al., 1978). In normal individuals VIP circulates at very low concentrations after ingestion of a meal (Bloom et al., 1975; Mitchell and Bloom in press). Recent studies in man have shown that VIP occurs throughout the central nervous system and in many peripheral tissues (Bryant, et al., 1976). In this present study, VIP concentrations are shown for the whole bowel thickness (muscle plus mucosa). However, it has been demonstrated in man that at least two-thirds of the total amount of VIP present in the gut occurs within tiny nerve fibres and nerve terminals of the muscle layer, the remainder being present in both nerve fibres and secretory cells in the mucosal layer (Bryant et al., 1976). Clearly the functional role of VIP may vary greatly depending on its location. The presence of VIP in nerve terminals suggests it may function in part as a neurotransmitter substance, while its location in endocrine cells suggests a possible paracrine, or local hormonal role.

Although, like VIP, enteroglucagon is widely distributed throughout the gut, it is not as uniformly distributed as the former peptide and is of maximal concentration in the distal small bowel. The isolation and purification of this substance has proved to be somewhat difficult because of its large molecular size, multiple hormonal forms, and relative instability. Hence little is known of its pharmacology.

The distribution of pancreatic glucagon immunoreactivity is markedly different from all the peptides discussed so far, this peptide being almost exclusively confined to the pancreas. This finding contrasts with the reports of Sasaki and co-workers (Sasaki et al., 1975) who found that, in the dog, at least a third of the total amount of pancreatic glucagon-like immunoreactivity present in this animal occurred in the fundic region of the stomach. In the primate, less than $0.01 \%$ occurred in this region. Histochemical analysis of the canine fundus has revealed numerous cells which are indistinguishable from pancreatic $\alpha$-cells, whereas $\alpha$-cells are absent or very infrequent in the primate stomach (Munõz Barragan et al., 1977). The absence of gastric pancreatic-type glucagon in the primate is additionally supported by observations on human surgical tissue where pancreatic glucagon-like immunoreactivity could also not be detected in the fundic region (Bloom $e t$ al., 1976a). In addition, circulating pancreatic glucagon is undetectable in the plasma of human subjects who have undergone total pancreatectomy (Barnes and Bloom, 1976).

It is now clear that most peptide hormones exist in several molecular forms of different size. The study of gut hormone distribution may thus be considered incomplete without characterisation of the type of molecular species measured. There is not space for a full account of such a study to appear in this report, so this will form the subject of a separate future communication. In brief, motilin and VIP eluted as single molecular species on gel chromatography and moved identically to the pure porcine peptides. CCK, pancreatic glucagon, and enteroglucagon were all multiform, having a pattern in agreement with previous reports (Rigopoulou et al., 1970; Valverde et al 1970). GIP also appeared to exist in at least two different molecular forms, the major peak of immunoreactivity eluting identically with pure porcine GIP standard, while a peak of apparent higher molecular weight GIP immunoreactivity was also observed. This higher molecular weight fraction formed approximately $20 \%$ of the total GIP immunoreactivity. It is perhaps pertinent to mention at this point that the biological potencies and halflives of the different molecular forms of these peptides cannot be assumed to be equivalent on a molar basis and clearly additional work is necessary to determine the relative physiological importance of the individual hormonal species measured.

The gut hormone maps reported here for the primate are the first to demonstrate the accurate relative distribution of seven different hormones in the same extracts of whole fresh bowel regions. They thus allow comparison of the total quantities of each hormonal peptide in the gut. This is essential basic data for the future study of gut hormonal pathophysiology.

This work was supported by grants from the British Diabetic Association, Medical Research Council, and the Wellcome Foundation. Pure porcine peptide hormones were a generous gift from Professor V. Mutt (Karolinska Institute, Stockholm, Sweden). Human serum albumin was kindly provided by the Lister Institute.

\section{References}

Adrian, T. E., Bloom, S. R., Bryant, M. G., Polak, J. M., Heitz, P., and Barnes, A. J. (1976). Distribution and release of human pancreatic polypeptide. Gut, 17, 940-944. Alford, F. P., Bloom, S. R., and Nabarro, J. D. N. (1977). Glucagon levels in normal and diabetic subjects: use of a specific immunoabsorbent for glucagon radioimmunoassay. Diabetologia, 13, 1-6.

Barnes, A. J., and Bloom, S. R. (1976). Pancreatectomised man: a model for diabetes without glucagon. Lancet, I, 219-221.

Bloom, S. R., and Bryant, M G. (1973). The distribution of vasoactive intestinal peptide (VIP) in the primate gastrointestinal tract and characterization of VIP from human tumours (Abstract). Gut, 14, 823. 
Bloom, S. R., Barnes, A. J., Bryant, M. G, and Alberti, K. G. M. M. (1976a). Plasma glucagon in diabetes resulting from total pancreatectomy. Metabolism, 25, 1481-1482.

Bloom, S. R., Bryant, M. G., and Cochrane, J. P. S. (1975). Normal distribution and postprandial release of gut hormones (Abstract). Clinical Science Molecular and Medicine 49, 3p.

Bloom, S. R., Mitznegg, P., and Bryant, M. G. (1976b). Measurement of human plasma motilin. Scandinavian Journal of Gastroenterology, II, Suppl. 39, 47-52.

Bryant, M. G., Bloom, S. R., Polak, J. M., Albuquerque, R. H., Modlin, I. M., and Pearse, A. G. E. (1976). Possible dual role for vasoactive intestinal peptide as gastrointestinal hormone and neurotransmitter substance. Lancet, I, 991-993.

Domschke, S. Domschke, W., Bloom, S. R., Mitznegg, P., Mitchell, S., Lux, G., Strunz, U., and Demling, L. (1978). In Gut Hormones, pp. 475-478. Edited by S. R. Bloom. Churchill Livingstone: Edinburgh.

Friedman, M. H. F., and Thomas, J. E. (1950). The assay and distribution of secretin. Journal of Laboratory and Clinical Medicine 35, 366-372.

Go, V. L. W., Hofmann, A. F., and Summerskill, W. H. J. (1969). Pancreozymin: sites of secretion and effects on pancreatic enzyme output in man (Abstract). Journal of Clinical Investigation 48, 29a-30a.

Häcki, W. H., Bloom, S. R., Mitznegg, P., Domschke, W., Domschke, S., Belohlavek, D., Demling, L., and Wünsch, E. (1977). Plasma secretin and pancreatic bicarbonate response to exogenous secretin in man. Gut, 18, 191-195.

Holohan, K. N., Murphy, R. F., Flanagan, R. W., Buchanan, K. D., and Elmore, D. T. (1973). Enzymic iodination of the histidyl residue of secretin: a radioimmunoassay of the hormone. Biochemica Biophysica Acta, 322, 178-180.

Hunter, W. M., and Greenwood, F. C. (1962). Preparation of iodine - 131 labelled human growth hormone of high specific activity. Nature, 194, 495-496.

Mitchell, S. J., and Bloom, S. R., (1978). Fasting and postprandial plasma VIP in man. Gut, 19, 1043-1048.

Modlin, I. M., Mitchell, S. J., and Bloom, S. R. (1978). The systemic release and pharmocokinetics of VIP. In Gut Hormones, pp. 470-474. Edited by S. R. Bloom. Churchill Livingstone: Edinburgh.
Munõz Barragan, L., Rufener, C., Srikant, C. B., Dobbs, R. E., Shannon, W. A., Jr, Baetens, D., and Unger, R. H. (1977). Immunocytochemical evidence for glucagoncontaining cells in the human stomach. Hormone Metabolism Research 9, 37-39.

Nilson, G., Yalow, R. S., and Berson, S. A. (1973). Distribution of gastrin in the gastrointestinal tract of human, dog, cat and hog. In Nobel Symposium XVI: Frontiers in Gastrointestinal Hormone Research. Edited by $\mathrm{S}$. Andersson. Stockholm, Almqvist. \& Wiksell.

O'Dorisio, T. M., Cataland, S., Stevenson, M., and Mazzaferri, E. L. (1976). Gastric inhibitory polypeptide (GIP): intestinal distribution and stimulation by amino acids and medium-chain triglycerides. American Journal of Digestive Diseases 21, 761-765.

Reeder, D. D., Becker, H. D., Smith, N. J., Rayford, P. L., and Thompson, J. C. (1973). Measurement of endogenous release of cholecystokinin by radioimmunoassay. Annals of Surgery 178, 304-310.

Rehfeld, J. F., Stadil, F., Malstrøm, J., and Miyata, M. (1975). Gastrin heterogeneity in serum and tissue. A progress report. In Gastrointestinal Hormones, pp. 43-58. Edited by J. C Thompson, University of Texas Press: Austin.

Rigopoulou, D., Valverde, I., Marco, J., Faloona, G. R., and Unger, R. H. (1970). Large glucagon immunoreactivity in extracts of pancreas. Journal of Biological Chemistry 245, 496-501.

Russell, R. C. G., Bloom, S. R., Fielding, L. P., and Bryant, M. G. (1976). Current problems in the measurement of gastrin release. A reproducible measure of physiological gastrin release. Postgraduate Medical Journal 52, 645-650.

Said, S. I., and Mutt, V. (1970). Polypeptide with broad biological activity: isolation from small intestine. Science, 169, 1217-1218.

Sasaki, H., Rubalcava, B., Baetens, D., Blazquez, E., Srikant, C. B., Orci, L., and Unger, R. H. (1975). Identification of glucagon in the gastrointestinal tract. Journal of Clinical Investigation, 56, 135-145.

Unger, R. H., Eisentraut, A., Sims, K., McCall, M. S., and Madison, L. L. (1961). Sites of origin of glucagon in dogs and humans (Abstract). Clinical Research, 9, 53.

Valverde, I., Rigopoulou, D., Marco, J., Faloona, G. R., and Unger, R. H. (1970). Characterization of glucagon-like immunoreactivity (GLI). Diabetes, 19, 614-623. 